\title{
Longitudinal study of workers exposed to mercury vapour at low concentrations: time course of inorganic and organic mercury concentrations in urine, blood, and hair
}

Nobuo Ishihara, Kenji Urushiyama

\begin{abstract}
Seven Japanese female workers exposed to mercury vapour at a concentration of $<0.02 \mathrm{mg} \mathrm{Hg} / \mathrm{m}^{3}$ (8 h/day, $44 \mathrm{~h} /$ week) were examined for inorganic (I-Hg) and organic ( $\mathrm{O}-\mathrm{Hg})$ mercury concentrations in urine, blood, and hair after $0,4,8,17$, and 23 months of exposure. Both I-Hg and $\mathrm{O}-\mathrm{Hg}$ concentrations in urine and hair did not increase significantly even after 23 months of exposure. The concentration of $\mathrm{I}-\mathrm{Hg}$ and $\mathrm{O}-\mathrm{Hg}$ in plasma and $\mathrm{O}$ $\mathrm{Hg}$ in erythrocytes, however, increased significantly after four months of exposure, and the high concentrations were maintained until the end of the study (23 months of exposure). Absence of a significant increase in the concentration of $\mathrm{O}-\mathrm{Hg}$ in hair indicates that changes in concentrations of $\mathrm{I}-\mathrm{Hg}$ and $\mathrm{O}-\mathrm{Hg}$ in blood could be caused by the occupational exposure to mercury vapour. These results show clearly that mercury concentration in blood indicates the uptake of mercury compared with data from before employment with mercury. Even after 23 months of exposure to mercury vapour, however, urinary mercury concentration was not affected.
\end{abstract}

(Occup Environ Med 1994;51:660-662)

Keywords: mercury vapour, inorganic mercury, organic mercury

In our previous report it was confirmed that four months of exposure to mercury vapour at low concentrations $\left(0.01-0.019 \mathrm{mg} \mathrm{Hg} / \mathrm{m}^{3} 8\right.$ $\mathrm{h} /$ day, $44 \mathrm{~h} /$ week) significantly increased concentrations of organic mercury $(\mathrm{O}-\mathrm{Hg})$ in erythrocytes and plasma-and inorganic mercury (I-Hg) in plasma but not in urine. ${ }^{\prime}$ Recently it was reported that in chloralkali workers also mercury concentrations in blood and urine were not significantly related to the duration of employment. ${ }^{2}$ These reports indicate that mercury concentrations in urine and blood might not necessarily increase if exposure to mercury vapour was low, less than the threshold limit value (TLV). Nevertheless clear uptake of mercury due to occupational exposure to mercury vapour has occurred.

Recently Barregard et al reported a two compartment model for urinary mercury excretion after brief occupational exposure. The half lives were 28 and 141 days. $^{3}$ Occupational exposure to mercury vapour, however, is not brief in most cases, and workers are engaged in mercury work daily for years. Therefore, the time course of mercury concentrations in biological samples (urine, blood, and hair) should be studied for longer periods than the half lives mentioned above, ${ }^{3}$ but few data are available.

The uptake of mercury through the diet (mainly by the consumption of fish and fish products) should be considered. The chemical form of mercury in fish and fish products is taken to be methylmercury. Owing to the interaction between inhaled mercury vapour and mercury accumulated in the human body through the diet, ${ }^{4-7}$ the time course of mercury concentration in biological samples might not be simple.

The aim of our report is to clarify the time course of mercury concentration in biological samples under exposure to mercury vapour at concentrations less than the TLV.

\section{Subjects and methods} SUBJECTS

The subjects were seven Japanese female workers in a mercury battery factory. They were among 14 subjects in the previous report. ${ }^{1}$ As seven of them retired after eight months of exposure, we followed up the rest to 23 months of exposure. They were 22 to 27 years old at the start of this study. They were examined five times during the 23 months including the examination before the start of mercury work - that is at $0,4,8,17$, and 23 months of exposure. None of them has had a history of occupational exposure to mercury and mercurials before this employment. To our regret, self administered questionnaires and psychometric tests shown in the report of Langworth et al could not be applied owing to the lack of skilled staff. ${ }^{8}$ During the course of the observation the women have not complained of symptoms suggestive of intoxication by mercury vapour.

The mercury concentrations in the air of the work places were $<0.02 \mathrm{mg} \mathrm{Hg} / \mathrm{m}^{3}$ throughout the study period. During the course of the study work places and materials were not changed. The exposure, therefore, should have been constant.

21 Dainas Hospital,

Japan.

Accepted 6 June 1994 
METHODS

Samples were collected on each occasion on the third Friday of the month starting in October, in the morning before the start of daily work as described previously. ${ }^{1}$

The selective determination of $\mathrm{I}-\mathrm{Hg}$ and total mercury ( $\mathrm{T}-\mathrm{Hg}$ ) was carried out by the method of Magos. ${ }^{9}$ The difference between values of $\mathrm{T}-\mathrm{Hg}$ and $\mathrm{I}-\mathrm{Hg}$ was taken as the value of $\mathrm{O}-\mathrm{Hg}$. According to the addition of pure mercuric chloride or methylmercury chloride, the detection limits of $\mathrm{I}-\mathrm{Hg}$ and $\mathrm{T}-\mathrm{Hg}$ in our laboratory were $1.67 \mathrm{pmol}$ of $\mathrm{Hg} / \mathrm{ml}$ of urine, $2 \cdot 5 \mathrm{pmol}$ of $\mathrm{Hg} / \mathrm{ml}$ of plasma and erythrocytes, and $1.0 \mathrm{pmol}$ of $\mathrm{Hg} / \mathrm{mg}$ of hair. All determinations were carried out in duplicate. The coefficient of variance was within $4.0 \%$ in all determinations.

STATISTICAL ANALYSIS

Means of concentrations of $\mathrm{I}-\mathrm{Hg}$ and $\mathrm{O}-\mathrm{Hg}$ after $4,8,17$, and 23 months of exposure were compared with their respective data at 0 months of exposure by the method of Scheffe $\left(\right.$ cited $\left.^{10}\right)$ after the analysis by Friedman test.

\section{Results}

Table 1 shows the means (SEM) of $\mathrm{I}-\mathrm{Hg}$ and $\mathrm{O}-\mathrm{Hg}$ in urine, plasma, erythrocytes, and hair and the results of the statistical analysis by Friedman test. The results of the Friedman test indicated that concentrations of $\mathrm{I}-\mathrm{Hg}$ and $\mathrm{O}-\mathrm{Hg}$ might be changed significantly in plasma and erythrocytes.

Table 2 shows the results of the statistical analysis by the method of Scheffe. It is clear that concentrations of $\mathrm{I}-\mathrm{Hg}$ and $\mathrm{O}-\mathrm{Hg}$ in plasma and concentration of $\mathrm{O}-\mathrm{Hg}$ in erythrocytes were increased significantly after four months of exposure. The unchanged concentration of $\mathrm{O}-\mathrm{Hg}$ in hair indicated that the intake of $\mathrm{O}-\mathrm{Hg}$ through the consumption of fish and fish products was almost constant during the study period, and so the changes of concentrations of $\mathrm{I}-\mathrm{Hg}$ and $\mathrm{O}-\mathrm{Hg}$ found in plasma and erythrocytes should have been due to the occupational exposure to mercury vapour. It is, therefore, clear that the concentrations of $\mathrm{I}-\mathrm{Hg}$ and $\mathrm{O}-\mathrm{Hg}$ in plasma and $\mathrm{O}-$ $\mathrm{Hg}$ in erythrocytes increased after four
Table 2 Statistical analysis of means by the method of Scheffe

\begin{tabular}{llllll}
\hline & \multicolumn{2}{l}{ Plasma } & & \multicolumn{2}{l}{ Erythrocytes } \\
\cline { 2 - 3 } & $I-H g$ & $O-H g$ & & $I: H g$ & $O-H g$ \\
\hline $0 v 4,8,17,23$ & $\star \star$ & $\star \star$ & & NS & $\star$ \\
$0,4 v 8,17,23$ & NS & NS & & NS & NS \\
$0,4,8 v 17,23$ & NS & NS & & NS & NS \\
$0,4,8,17 v 23$ & NS & NS & & NS & NS \\
\hline
\end{tabular}

${ }^{\star} \mathrm{p}<0.05 ;{ }^{\star \star} \mathrm{p}<0.01$

months of exposure and the high levels of mercury were maintained until the end of the study. Concentrations of $\mathrm{I}-\mathrm{Hg}$ and $\mathrm{O}-\mathrm{Hg}$ in urine did not increase despite the clear uptake of mercury by occupational exposure.

\section{Discussion}

In this study $\mathrm{O}-\mathrm{Hg}$ has been estimated by subtraction, after the estimation of $\mathrm{T}-\mathrm{Hg}$ and I-Hg by the method of Magos. ${ }^{9}$ Any underestimate of $\mathrm{I}-\mathrm{Hg}$ would result in an overestimation of $\mathrm{O}-\mathrm{Hg}$. The intralaboratory comparison of mercury measurement by different methods (AAS (atomic absorbtion selection) by the method of Magos, ${ }^{9}$ ECD (electron capture detection) gas chromatography after extraction, AAS after acid digestion ${ }^{11}$ ), however, showed good agreement, and indicated that the data for $\mathrm{T}-\mathrm{Hg}, \mathrm{I}-\mathrm{Hg}$, and $\mathrm{O}-\mathrm{Hg}$ found by the method of Magos would be applicable in the study of biotransformation of methylmercury in humans. Any underestimation of I$\mathrm{Hg}$, therefore, should be excluded.

In the occupational exposure to mercury vapour at low concentrations the consumption of fish and fish products is one of the main routes of mercury uptake. Also, the daily consumption of fish and fish products differs between individuals. To minimise this anticipated individual difference and to detect slight changes of $\mathrm{I}-\mathrm{Hg}$ and $\mathrm{O}-\mathrm{Hg}$ concentrations due to occupational exposure, therefore, the longitudinal and repeated study of the same subjects is ideal.

The results of statistical analysis (table 2) indicated clearly that the concentrations of I$\mathrm{Hg}$ and $\mathrm{O}-\mathrm{Hg}$ in plasma and $\mathrm{O}-\mathrm{Hg}$ in erythro-

Table 1 Mean (SEM) inorganic and organic mercury concentrations in urine, plasma, erythrocytes, and hair

\begin{tabular}{|c|c|c|c|c|c|c|}
\hline & \multicolumn{5}{|c|}{ Time after job assignment (months) } & \multirow{2}{*}{$\begin{array}{l}\text { Friedman } \\
\text { test }\end{array}$} \\
\hline & 0 & 4 & 8 & 17 & 23 & \\
\hline $\begin{array}{l}\text { Urine (pmol } \\
\text { I- } \mathrm{Hg} \\
\mathrm{O}-\mathrm{Hg}\end{array}$ & $\begin{array}{c}\mathrm{Hg} / \mathrm{g} \text { creatinine }): \\
12.92(3.76) \\
0.80(0.28)\end{array}$ & $\begin{array}{r}14.29(2.46) \\
1.95(0.45)\end{array}$ & $\begin{array}{r}15.39(3.06) \\
1.73(0.73)\end{array}$ & $\begin{array}{r}10.66(1.28) \\
1.13(0.27)\end{array}$ & $\begin{array}{r}15.26(2.05) \\
1.35(0.25)\end{array}$ & $\begin{array}{l}\text { NS } \\
\text { NS }\end{array}$ \\
\hline $\begin{array}{l}\text { Plasma (pmo } \\
\text { I- } \mathrm{Hg} \\
\mathrm{O}-\mathrm{Hg}\end{array}$ & $\begin{array}{c}\mathrm{Hg} / \mathrm{ml} \text { plasma): } \\
2 \cdot 49(0.42) \\
4 \cdot 14(0.74)\end{array}$ & $\begin{array}{r}8.61(0.53) \\
10.43(2.66)\end{array}$ & $\begin{array}{l}4 \cdot 24(0 \cdot 88) \\
7 \cdot 17(2 \cdot 72)\end{array}$ & $\begin{array}{l}5.33(0.56) \\
9.14(1.46)\end{array}$ & $\begin{array}{l}2 \cdot 84(0.49) \\
8 \cdot 14(1.49)\end{array}$ & $\star \star \star$ \\
\hline $\begin{array}{l}\text { Erythrocytes } \\
\text { I-Hg } \\
\mathrm{O}-\mathrm{Hg}\end{array}$ & $\begin{array}{r}\text { pmol Hg/ml): } \\
8 \cdot 27(2 \cdot 18) \\
54 \cdot 38(8 \cdot 80)\end{array}$ & $\begin{array}{l}12 \cdot 43(4 \cdot 78) \\
86 \cdot 61(19 \cdot 92)\end{array}$ & $\begin{array}{c}5.23(2.53) \\
94.02(20.57)\end{array}$ & $\begin{array}{l}27.99(8.53) \\
95.79(15.25)\end{array}$ & $\begin{array}{r}5 \cdot 15(2 \cdot 41) \\
123 \cdot 27(11 \cdot 61)\end{array}$ & $\stackrel{\star}{\star \star}$ \\
\hline $\begin{array}{l}\text { Hair (pmol H } \\
\text { I-Hg } \\
\text { O-Hg }\end{array}$ & $\begin{array}{l}\mathrm{g} / \mathrm{mg} \text { hair }): \\
1.67(0 \cdot 20) \\
8 \cdot 70(1 \cdot 80)\end{array}$ & $\begin{array}{l}2.51(0.32) \\
8.60(1.48)\end{array}$ & $\begin{array}{l}2.29(0.24) \\
7.79(1.15)\end{array}$ & $\begin{array}{r}2.37(0.59) \\
10.47(2.82)\end{array}$ & $\begin{array}{l}2.18(0.22) \\
9.23(0.85)\end{array}$ & $\begin{array}{l}\text { NS } \\
\text { NS }\end{array}$ \\
\hline
\end{tabular}

Friedman test: ${ }^{\star} \mathrm{p}<0.05 ;{ }^{\star \star} \mathrm{p}<0.01$. 
cytes increased significantly after four months of exposure, and that these mercury concentrations seemed to be in a steady state after four months of exposure. The increase in the concentration of $\mathrm{I}-\mathrm{Hg}$ in plasma should be the result of uptake of mercury due to the occupational exposure to mercury vapour. The interaction between the inhaled mercury and mercury accumulated through the diet might result in the redistribution of $\mathrm{O}-\mathrm{Hg} .^{4}{ }^{7}$ The increase of $\mathrm{O}-\mathrm{Hg}$ concentration in plasma and erythrocytes should be mainly the result of this redistribution of $\mathrm{O}-\mathrm{Hg}$ initiated by the inhaled mercury vapour.

The question might arise why not only I$\mathrm{Hg}$ but also $\mathrm{O}-\mathrm{Hg}$ did not increase continuously despite continuous uniform exposure. This might be the result of the increased capacity of binding sites that are known to have a higher affinity to $\mathrm{I}-\mathrm{Hg}$ than $\mathrm{O}-\mathrm{Hg},{ }^{12}$ and it might be due to the induction of binding sites such as metallothionein.

The concentration of $\mathrm{I}-\mathrm{Hg}$ in plasma and $\mathrm{O}-\mathrm{Hg}$ in plasma and erythrocytes, therefore, increased after four months of exposure and stayed increased. The concentration of $\mathrm{I}-\mathrm{Hg}$ in the critical organs such as kidneys and brain might continue to increase along with the continuous exposure to mercury vapour. This might coincide with the consideration that there is no suitable biological index of concentration of $\mathrm{I}-\mathrm{Hg}$ in the critical organs. ${ }^{1314}$

Langworth et al reported that the mercury concentrations in blood and urine in chloralkali workers were significantly related to the type of work but not to the length of employment. As the minimum length of exposure was a year in the report, ${ }^{2}$ it is suggested that the mercury concentration would have been already constant in blood and urine at the time of sampling.

Our present results indicate that concentrations of $\mathrm{I}-\mathrm{Hg}$ and $\mathrm{O}-\mathrm{Hg}$ in blood might be useful indicators of mercury uptake so long as data from before work with mercury are available. Subjective symptoms, ${ }^{8}$ tremor, ${ }^{1517}$ and enzymuria ${ }^{151819}$ should be assessed alongside mercury determination in biological samples during the assessment of exposure to mercury vapour.
We are indebted to Dr Sven Langworth (Huddinge Hospital, Sweden) for reading the manuscript and for his valuable comments.

A part of this work was presented at the 22nd Meeting of ICOH, Sydney, Australia (27 September-2 October, 1987).

1 Ishihara $\mathrm{N}$, Urushiyama $\mathrm{K}$, Suzuki $\mathrm{T}$. Inorganic and organic mercury in blood, urine and hair of low level mercury vapour exposure. Int Arch Occup Environ Health 1977; 40:249-53.

2 Langworth S, Elinder C-G, Goethe C-J, Vesterberg O. Biological monitoring of environmental and occupational exposure to mercury. Int Arch Occup Environ Health 1991;63:161-7.

3 Barregard L, Saellsten G, Schutz A, Attewell R, Skerfving S, Jaerrholm B. Kinetics of mercury in blood and urine after brief occupational exposure. Arch Environ Health 1992;47:176-84.

4 Ishihara N, Shiojima $S$, Suzuki T. Selective enhancement of urinary organic mercury excretion by D-penicillamine Brf Ind Med 1974;31:245 $\cdots 9$.

5 Suzuki T, Shishido $S$. Changes of levels of urinary organic mercury in groups with varying extent of inorganic mercury. Tohoku $\mathcal{F}$ Exp Med 1974;112:101-2.

6 Suzuki T, Shishido S, Ishihara N. Different behaviour of inorganic and organic mercury in renal excretion with reference to effects of D-penicillamine. $\mathrm{Br} \mathcal{F}$ Ind $\mathrm{Med}$ 1976;33:88-91

7 Suzuki T, Shishido S, Ishihara $\mathrm{N}$. Interaction of inorganic to organic mercury in their metabolism in the human body. Int Arch Occup Environ Health 1976;38:103 -13.

8 Langworth S, Almkvist O, Soederman E, Wikstroem B-O. Effects of occupational exposure to mercury vapour on the central nervous system. Br $₹$ Ind Med 1992;49: the central

9 Magos L. Selective atomic-absorption determination of inorganic mercury and methylmercury in undigested biological samples. Analyst 1971;96:841-53

10 Wallenstein S, Zucker CL, Fleiss JL. Some statistical methods useful in circulation research. Circ Res 1980;47: $1-9$

11 Matsuo N, Suzuki T, Akagi H. Mercury concentration in organs of contemporary Japanese. Arch Environ Health 1989;44:298-303.

12 Clarkson TW, Magos L. Studies on the binding of mercury in tissue homogenate. Biochem $\mathcal{F} 1966 ; 99: 62 \cdots 70$.

13 Skerfving S, Berlin M. Nordiska expertgruppen foer graensvaerdesdokumentation 59. Oorganiskt Kvickgraensvaerdesdokumentation 59 . Or. In Swedish with
silver. Arbete och Haelsa 1985;20:1-78. (In Swe Silver. Arbete och Hary.)

14 Elinder CG, Gerhardsson L, Oberdoerster G. Biological monitoring of toxic metals-over view. In: Clarkson TW, Friberg L, Nordberg GF, Sager PR, eds. Biological monitoring of toxic metals. New York: Plenum Press, 1988: $1-71$

15 Roels H, Gennart JP, Lauwerys R, Buchet JP, Malcaire J, Bernard A. Surveillance of workers exposed to mercury vapour: variation of a previously proposed biological vapour. variation of a previously proposed biological Am F Ind Med 1985;7:69-74.

16 Verberk MM; Salle HJA, Kemper CM. Tremor in workers with low exposure to metallic mercury. Am Ind Hyg Assoc 7 1986;47:559-62.

17 Roels H, Abdeladim S, Braun M, Malchaire J, Lauwerys $R$. Detection of hand tremor in workers exposed to mercury vapour. Environ Res 1989;49:152 -65

18 Barregard L, Hultherg B, Schitz A, Saellsten G. Enzymuria in workers exposed to inorganic mercury. Int Arch Occup Environ Health 1988;61:659.

19 Langworth S, Flinder CG, Sundquist KG, Vesterberg O. Renal and immunological effects of occupational exposure to inorganic mercury. $B r f$ Ind Med 1992;49: 394-401. 